\title{
Dentists in Nepal: A Situation Analysis
}

\author{
Rabindra Man Shrestha, ${ }^{1}$ Sujita Shrestha, ${ }^{2}$ Nischal Kunwar ${ }^{3}$ \\ ${ }^{1}$ Department of Orthodontics, ${ }^{2}$ Department of Public Health Dentistry, ${ }^{3}$ Dental Surgeon, Kantipur Dental \\ College, Kathmandu, Nepal.
}

\begin{abstract}
Background: Human resource data is essential for planning and implementation of health care delivery system. However, very few information is available on dental health human resource in the country. The aim of study was to assess the number of dentists in the country and to explore their distribution according to demographic and professional characteristics.

Methods: A census was performed during July 2015 to July 2016 about the Nepali dentists. The study assessed demographic and professional characteristics of dentists including age, gender, ethnicity, education attainment, university, country/year of graduation, and work place using data collection sheet by trained data collectors. For those not accessible for direct contact, the information was obtained through secondary data. Data entry was done in CSPro software application and was analyzed in SPSS 20.

Results: The total number of registered Nepali dentists was 1803 with 419 specialists until June 2015. The male to female ratio was 1:1.46. Among all; 1318 (73\%) were present in the country, 1047 (58\%) were professionally active, and 1366 (76\%) were below the age of 35 years. Among the professionals; 831 (79\%) were employed in private sector and 601 (57\%) worked in Kathmandu valley.

Conclusions: The dentist-population ratio is decreasing exponentially in capital and major cities of Nepal however it remains very high in rural areas. Compared to other provinces, Province 6 and Province 7 lack service of dentists.

Keywords: Census; dentist; dentist-population ratio; human resource; specialist.
\end{abstract}

\section{INTRODUCTION}

Dental health human resource play important role in the provision of health care. In recent years, the number of dentists has increased remarkably in Nepal. Presently there is a production of about 500 dentists per year. ${ }^{1,2}$

National Oral Health Policy has the strategic plan to recruit dental service at district and PHC level. ${ }^{3}$ Nepal government has included basic oral health service as a component of essential health care package. ${ }^{4}$ Effective health service demands adequate number of human resource with proper allocation and management. ${ }^{5,6}$ There is a tendency to accumulate the professionals in capital and urban cities; and proper job allocation has not been suitably planned in Nepal. ${ }^{7}$ The information on human resource in health $(\mathrm{HRH})$ situation of the dentists is scarce. Thus, this study aimed to assess the number of Nepali dentists and their distribution according to demographic and professional characteristics; and to depict the service mapping data of dentists in Nepal.

\section{METHODS}

A census of Nepali dentists was performed during July 2015 to July 2016. The Nepali dentist was defined as the Nepali health professional with the qualification of Bachelor of Dental Surgery (BDS) or an equivalent degree, and Nepali dental specialist was defined as the Nepali dentist with additional specialty qualification of Master's degree or an equivalent qualification in any dental science subject, basic science subject or public health from recognized university/institution, registered with the Nepal Medical Council (NMC). The research project obtained ethical clearance from Nepal Health Research Council.

A complete list of Nepali dentist was obtained from Nepal Medical Council Doctor's List (July 2014) ${ }^{8}$ and the updated list till June 2015 was obtained from NMC office. The study assessed detailed information regarding the demographic and professional characteristics of the Nepali dentists. The demographic 
characteristics included age, gender, ethnicity, address; and professional characteristics included education attainment, university, country/year of graduation, specialization (if any) and workplace. The ethnicity was determined according to the caste listed in Central Bureau of Statistics report..$^{9,10}$ While determining the workplace; the full-time and institutional involvement were considered. Data of the eleven deceased dentists were not included in the study.

The present locations of dentists were determined from employee dentist's list obtained from Health Services Department/MoH, dental/medical colleges, private hospitals, and communication through Nepal Dental Association regional branches.

A data collection sheet was developed to collect the information regarding demographic and professional details. Data were collected after receiving written consent from the respondents. Trained data collectors visited dentists in various parts of the country. For those not accessible for direct contact, the information was obtained through secondary data gathered from Nepal Medical Council's website, ${ }^{11}$ Nepal Dental Association Dental Directory, ${ }^{12}$ Nepal Dental Association membership form, information from the peer and key informants, and through the social networking sites. Data entry was done in CSPro software application. ${ }^{13}$ Data analysis was done in SPSS Version 20 program for category description.

\section{RESULTS}

The total number of registered Nepali dentists was 1803 as per the list obtained from Nepal Medical Council until June 2015. Mean age of the Nepali dentists was 32.54 $( \pm 6.68)$ years. The numbers of female and male dentists were $1070(59.35 \%)$ with mean age $31.72( \pm 5.67)$ years and $733(40.65 \%)$ with mean age $33.73( \pm 7.79)$ years respectively. The number of dentists below the age of 25 years was 79 (4.38\%), 26-30 years was 779 (43.21\%), 3135 years was $508(28.18 \%), 36-40$ years was $252(13.98 \%)$, 41-45 years was 106 (5.88\%), 46-50 years was $46(2.55 \%)$, 51-60 years was $18(0.99 \%), 61-70$ years was $11(0.61 \%)$ and above 71 years was $4(0.22 \%)$. According to the study, the Khas Arya ethnicity comprised of majority of the total Nepali dentist population, followed by Newars and Madhesis (Table 1).

\begin{tabular}{|c|c|c|}
\hline Ethnicity & & \\
\hline \multirow{2}{*}{$\begin{array}{l}\text { Khas Arya/Hill } \\
738 \text { (40.93\%) }\end{array}$} & Brahmin & 541 (73.31\%) \\
\hline & Chhetri/Thakuri & 197 (26.69\%) \\
\hline \multicolumn{2}{|l|}{ Newar } & 534 (29.61\%) \\
\hline \multirow{6}{*}{$\begin{array}{l}\text { Madhesi/Terai } \\
378(20.96 \%)\end{array}$} & Madhesi & 296 (78.31\%) \\
\hline & Marwari & $33(8.73 \%)$ \\
\hline & Muslim & $26(6.88 \%)$ \\
\hline & Tharu/Rajbansi & $20(5.29 \%)$ \\
\hline & Jain & $2(0.51 \%)$ \\
\hline & Sikh & $1(0.26 \%)$ \\
\hline \multirow{7}{*}{$\begin{array}{l}\text { Janjati } \\
127(7.04 \%)\end{array}$} & Gurung & 46 (36.22\%) \\
\hline & Magar & $23(18.11 \%)$ \\
\hline & Rai & $18(14.17 \%)$ \\
\hline & Limbu & 14 (11.02\%) \\
\hline & Thakali & $13(10.24 \%)$ \\
\hline & Sherpa & 7 (5.51\%) \\
\hline & Tamang/Lama & $6(4.72 \%)$ \\
\hline \multicolumn{2}{|l|}{ Sanyasi/Giri } & $13(0.72 \%)$ \\
\hline \multicolumn{2}{|l|}{ Dalit } & 7 (0.39\%) \\
\hline \multicolumn{2}{|c|}{$\begin{array}{l}\text { Migrants (Indian 3, Chinese/ } \\
\text { Tibetan 2, Filipino 1) }\end{array}$} & $6(0.33 \%)$ \\
\hline
\end{tabular}

Table 2. Distribution of dentists and dental specialists according to country and university of graduation.

$\begin{array}{llll}\text { Country } & & \text { Level } & \text { University } \\ \text { Nepal } & \text { B } & 998(55.35 \%) & \text { TU-538, BPKIHS-379, KU-81 } \\ & \text { M } & 188(44.87 \%) & \text { KU-92, BPKIHS-49, TU-36, NAMS-11 }\end{array}$

Manipal-263, RGUHS-36, LN Mithila-34, Kuvempu-19, Karnatak-10, Magadh-9, Mysore-8, Patna-7, Lucknow-5, Bangalore-6, Bombay-4, $443(24.57 \%) \quad K e r a l a-4$, Calcutta-3, Meerut-3, KGMU-2, Osmania-2, RML Avadh-2, MGRMU-2, Madras-2, Goa-2, Guwahati-1, Indore-1, Delhi-1, Punjab-1,

India Gujarat-1, Gulbarga-1, Shivaji-1, Tamilnadu-1, Health Science Vijayawada-1, NA-11

RGUHS-10, AllMS-6, KGMU-6, Manipal-4, Lucknow-2, Nagpur-2, M $38(9.07 \%) \quad$ Mumbai-1, Bharati Vidyapeeth-1, NTRUHS-1, BHU-1, Chitra Tirunal-1, Agra-1, MGRMU-1, NA-1 


\begin{tabular}{|c|c|c|c|}
\hline \multirow[t]{2}{*}{ Bangladesh } & B & $264(14.64 \%)$ & Dhaka-248, Rajshahi-16 \\
\hline & M & $20(4.77 \%)$ & BSMMU-15, North South-2, Dhaka-1, State-1, American Int'l-1 \\
\hline \multirow{2}{*}{ Pakistan } & B & $47(2.61 \%)$ & Health Sciences Lahore-17, Punjab-15, Sind-13, Liaquat-2 \\
\hline & M & $4(0.95 \%)$ & College of Physicians \& Surgeons \\
\hline \multirow[t]{2}{*}{ USSR/CIS } & B & $21(1.16 \%)$ & $\begin{array}{l}\text { Tver Russia-4, Chuvash Russia-2, Volgograd Russia-2, Lviv Ukraine-2, } \\
\text { Odessa Ukraine-2, Kyrgyzstan-2, Moscow Russia-1, Dagestan Russia-1, } \\
\text { Kuban Russia-1, Kharkiv Ukraine-1, Kiev Ukraine-1, Dnipropetrovsk } \\
\text { Ukraine-1, Azerbaijan-1 }\end{array}$ \\
\hline & M & $6(1.43 \%)$ & $\begin{array}{l}\text { Kyrgyzstan-2, Tver Russia-1, Volgograd Russia-1, Crimea Russia-1, Lviv } \\
\text { Ukraine-1 }\end{array}$ \\
\hline \multirow{2}{*}{ Philippines } & B & $19(1.05 \%)$ & Baguio-6, South Western-6, Emilio Aguinaldo-4, East-2, Fatima-1 \\
\hline & M & $24(5.73 \%)$ & East-11, Philippines-6, Manila Central-6, Centro Escolar-1 \\
\hline \multirow[b]{2}{*}{ Australia } & B & $5(0.28 \%)$ & Adelaide University \\
\hline & M & $8(1.91 \%)$ & $\begin{array}{l}\text { Curtin-2, Sydney-2, New South Wales-1, Western Sydney-1, } \\
\text { Wollongong-1, NA-1 }\end{array}$ \\
\hline \multirow{2}{*}{ Sri Lanka } & B & $1(0.05 \%)$ & Peradeniya University \\
\hline & M & $1(0.24 \%)$ & Colombo University \\
\hline \multirow{2}{*}{ Japan } & B & $1(0.05 \%)$ & Hokkaido University \\
\hline & M & $1(0.24 \%)$ & Kyushu University \\
\hline Myanmar & B & $1(0.05 \%)$ & University of Dental Medicine \\
\hline Fiji & B & $1(0.05 \%)$ & South Pacific University \\
\hline Poland & B & $1(0.05 \%)$ & NA \\
\hline Germany & B & $1(0.05 \%)$ & NA \\
\hline
\end{tabular}

\begin{tabular}{|c|c|c|c|}
\hline China & M & $88(21.00 \%)$ & $\begin{array}{l}\text { Huazhong-19, Sichuan-12, Jiamusi-11, Dalian-9, Zhengzhou-9, Nanjing-7, } \\
\text { Xin Jiang-4, Chongqing-3, Hebei-2, Liaoning-2, X'ian-1, Tongji-1, } \\
\text { Shanghai Jiao Tong-1, Sun Yat Sen-1, Jinzhou-1, Yangte-1, Xingya Central } \\
\text { South-1, Jinzhou-1, NA-2 }\end{array}$ \\
\hline UK & M & $12(2.86 \%)$ & $\begin{array}{l}\text { RCS Edinburgh-3, King's College GKT-3, RCS London-1, RCPS Glasgow-1, } \\
\text { London-1, East London-1, NA-2 }\end{array}$ \\
\hline USA & M & $10(2.39 \%)$ & $\begin{array}{l}\text { Washington-2, John Hopkins-1, Tufts-1, Southern-1, Indiana-1, } \\
\text { Pennsylvania-1, American Public Univ System-1, Texas A\&M-1, NA-1 }\end{array}$ \\
\hline Thailand & M & $10(2.39 \%)$ & Mahidol University \\
\hline Norway & M & $5(1.19 \%)$ & Bergen University \\
\hline Hong Kong & M & $1(0.24 \%)$ & Hong Kong University \\
\hline Singapore & M & $1(0.24 \%)$ & National University \\
\hline Finland & M & $1(0.24 \%)$ & Eastern Finland University \\
\hline Canada & M & $1(0.24 \%)$ & University of Toronto \\
\hline
\end{tabular}

\section{B: Bachelor level ( $n=1803)$, M: Master level ( $n=419)$, NA: Data not available}

The study showed that the maximum number of Nepali dentists graduated from Nepali universities. A total of 998 (55.35\%) Nepali dentists completed Bachelor level degree and 188 (44.87\%) completed Master level degree from Nepal (Table 2). The study showed that the number of Nepali dental graduates increased remarkably after the year 2005 (Figure 1).

There were 419 specialist dentists with specialty in dentistry, basic science or public health subjects. About 314 dentists were pursuing post graduate education in the country and abroad (Figure 2). Among the professionally active dentists; 601 (57.40\%) were working in Kathmandu Valley and 446 (42.6\%) were working outside Kathmandu Valley. The study showed that, 34 districts were not served by any dentist, 19 districts were served by one or two dentists only. Districts like Morang, Sunsari, Kathmandu, Lalitpur, Bhaktapur, Chitwan, Parsa, Kaski, and Rupendehi were served by more than 30 dentists (Figure 4). 


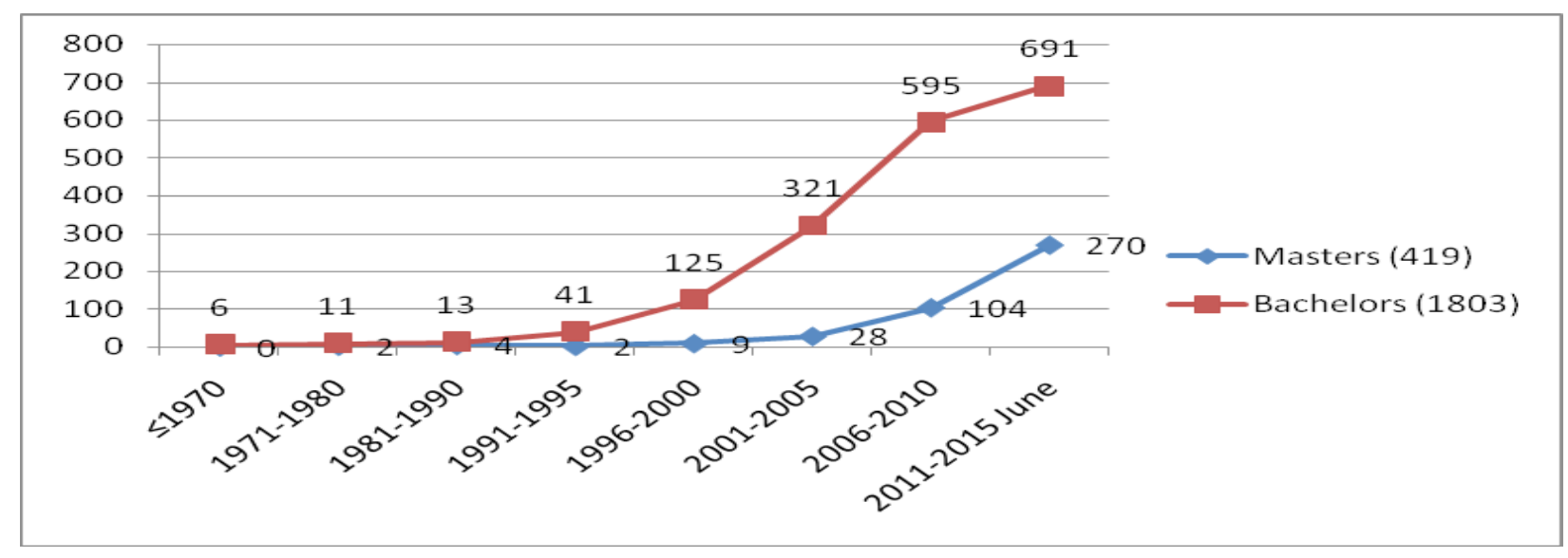

\section{Figure 1. Distribution of dentists and dental specialists according to year of graduation.}

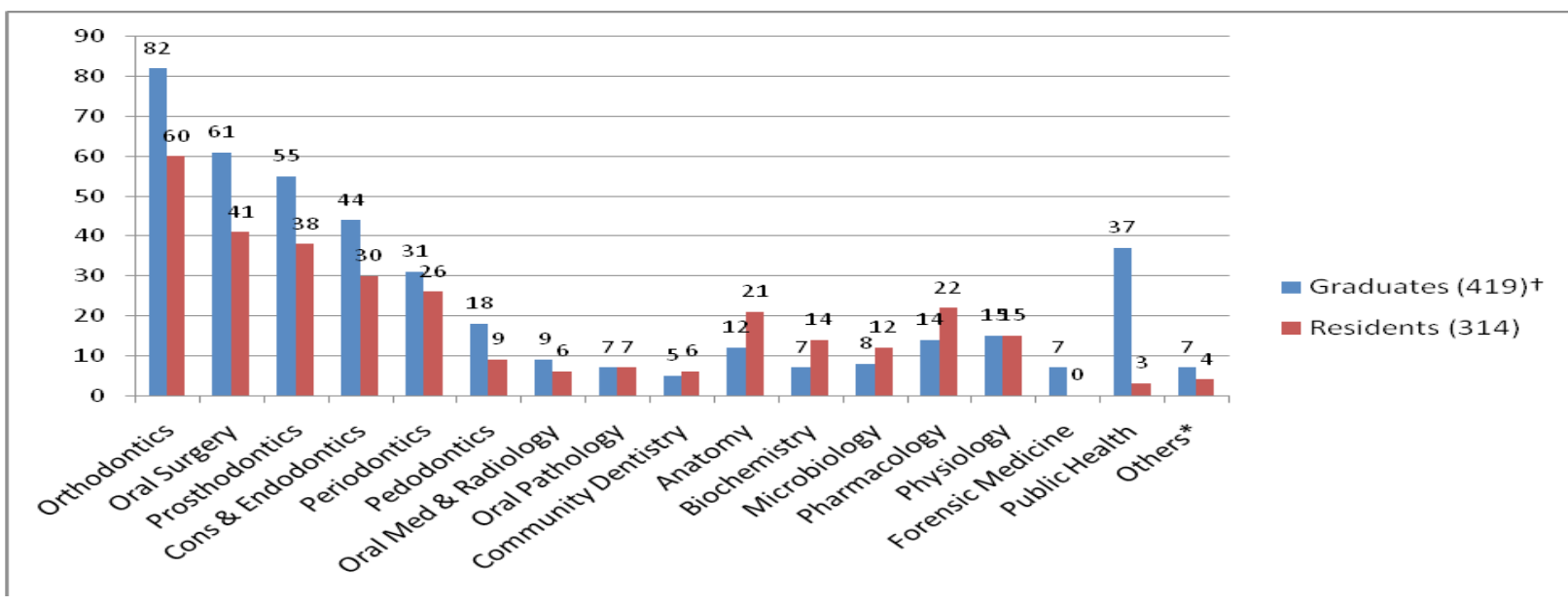

Figure 2. Distribution of dental specialists and residents according to specialty subjects.

* Maxillofacial Prosthesis, Oral Implantology, Oral Biology, Dental Materials. ${ }^{\top}$ MDS/MSD-301, PhD-7, FCPS-4, FDS-3, MSc-4, DOrtho-1; MD-50, MS-12, MPH-33, DPH-3, DDPHRCS-1

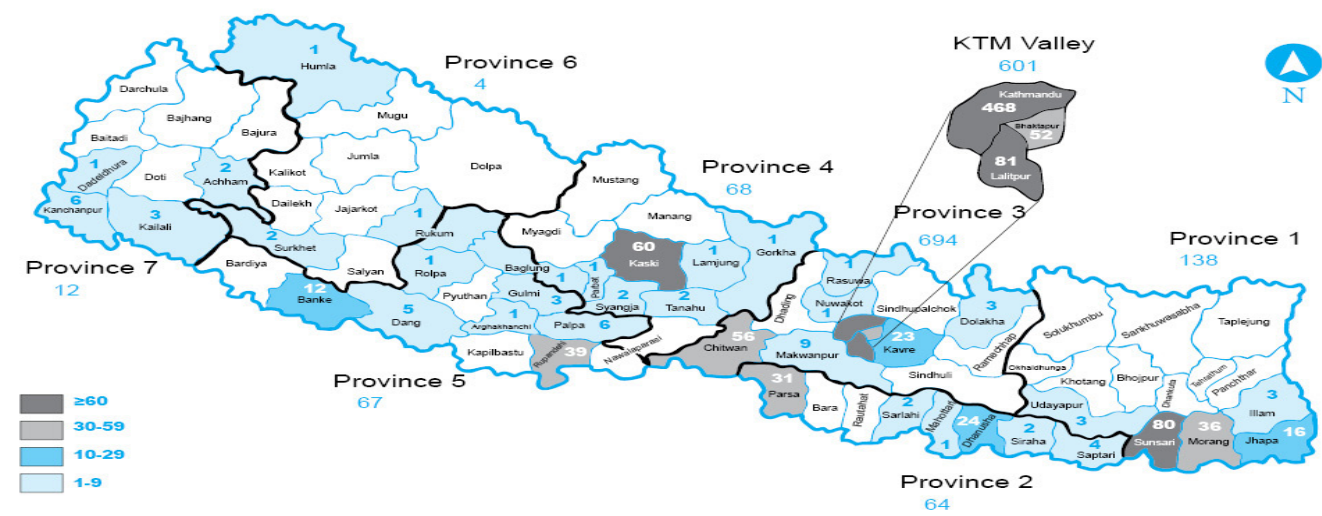


Table 3. Present status and job distribution of Nepali dentists $(n=1803)$.

\section{Particulars}

Number

Present Status

\begin{tabular}{|c|c|c|}
\hline \multirow{4}{*}{$\begin{array}{l}\text { Present in Nepal } \\
1318(73.10 \%)\end{array}$} & $\begin{array}{l}\text { Professionally } \\
\text { active }\end{array}$ & $\begin{array}{r}1047 \\
(79.44 \%)\end{array}$ \\
\hline & $\begin{array}{l}\text { Studying PG (MDS, } \\
M D, M S)\end{array}$ & $\begin{array}{r}200 \\
(15.17 \%)\end{array}$ \\
\hline & $\begin{array}{l}\text { Not working } \\
\text { (retired, not } \\
\text { employed, exam } \\
\text { preparation) }\end{array}$ & $\begin{array}{r}45 \\
(3.41 \%)\end{array}$ \\
\hline & Status unknown & $\begin{array}{r}26 \\
(1.97 \%)\end{array}$ \\
\hline \multirow{4}{*}{$\begin{array}{l}\text { In foreign country* } \\
485(26.90 \%)\end{array}$} & $\begin{array}{l}\text { Practicing } \\
\text { dentistry }\end{array}$ & $\begin{array}{r}159 \\
(32.78 \%)\end{array}$ \\
\hline & $\begin{array}{l}\text { Studying PG } \\
\text { (MDS/MPH/PhD } \\
\text { etc.) }\end{array}$ & $\begin{array}{r}114 \\
(23.5 \%)\end{array}$ \\
\hline & $\begin{array}{l}\text { Other } \\
\text { employment }\end{array}$ & $\begin{array}{r}58 \\
(11.96 \%)\end{array}$ \\
\hline & Status unknown & $\begin{array}{r}154 \\
(31.75 \%)\end{array}$ \\
\hline
\end{tabular}

Deceased $^{\dagger}$

Full-time Work place (In Nepal)

\begin{tabular}{|c|c|c|}
\hline \multirow{3}{*}{$\begin{array}{l}\text { Private clinic/ } \\
\text { hospital } \\
524(49.76 \%)\end{array}$} & Employed & $\begin{array}{r}320 \\
(61.07 \%)\end{array}$ \\
\hline & Self-employed & $\begin{array}{r}197 \\
(37.59 \%)\end{array}$ \\
\hline & NGO/INGO & $7(1.33 \%)$ \\
\hline \multirow{2}{*}{$\begin{array}{l}\text { University Teaching } \\
\text { Hospital } \\
376(35.90 \%)\end{array}$} & $\begin{array}{l}\text { Dental College/ } \\
\text { Program }\end{array}$ & $\begin{array}{r}278 \\
(73.94 \%)\end{array}$ \\
\hline & Medical College & $\begin{array}{r}98 \\
(26.06 \%)\end{array}$ \\
\hline \multirow{3}{*}{$\begin{array}{l}\text { Government Hospital } \\
107(10.44 \%)\end{array}$} & Permanent & $\begin{array}{r}21 \\
(19.63 \%)\end{array}$ \\
\hline & Contract & $\begin{array}{r}85 \\
(79.44 \%)\end{array}$ \\
\hline & $\begin{array}{l}\text { Civil Service } \\
\text { Hospital }\end{array}$ & $1(0.93 \%)$ \\
\hline \multirow{3}{*}{$\begin{array}{l}\text { Law enforcement } \\
\text { organizations } \\
40(3.90 \%)\end{array}$} & Army & $\begin{array}{r}25 \\
(62.5 \%)\end{array}$ \\
\hline & Police & $\begin{array}{r}13 \\
(32.5 \%)\end{array}$ \\
\hline & Armed Police & $2(5.0 \%)$ \\
\hline
\end{tabular}

*USA-162, Australia-68, UK-64, China-56, India-34, Canada-21, Philippines-19, Bangladesh-16, Norway-8, Japan-7, Pakistan-6, Thailand-4, Singapore-2, Germany-2, Russia-2, Armenia-1, Carribian-1, Hong Kong-1, Iran-1, Korea-1, Netherlands-1, Qatar-1, Saudi Arabia-1, South Sudan-1, Unknown-5

tData of the deceased not included
Among the total number of Nepali dentists; 1318 (73.10\%) were present in the country and 1047 (58.07\%) were professionally active. A total of 831 (79.37\%) professionally active dentists were employed in private sector in private clinics/hospitals, private medical/dental colleges and NGO's; and 216 (20.63\%) were working in government sector including government hospitals, law enforcing organizations and government medical/dental colleges (Table 3).

Among the dentists with specialty qualification; 251 $(60 \%)$ work as faculty in dental or medical colleges. It was found that, approximately $27 \%$ of the professional dentists work in additional workplace. Majority of the dentists working in public sector and academia serve extra time at private clinics. Besides regular full time job, 155 dentists were also employed in private clinics/hospitals, 197 dentists worked in own clinics, 2 in NGO clinics, 6 in dental colleges, 1 in Civil Service Hospital and 1 in Armed Force Hospital during extra hours.

\section{DISCUSSION}

The Human Resource Information System (HuRIS) ${ }^{14}$ of Ministry of Health $(\mathrm{MoH})$ and Personal Information System (PIS) $)^{15}$ of Ministry of General Administration are not effective in providing HR information on dental health. Recently, MoH has announced the commencement of Health Workforce Registry in the country. Nepal Medical Council periodically publishes the list of registered medical doctors ${ }^{8}$ with basic information only. On the other hand Nepal Dental Association Dental Directory ${ }^{12}$ provides professional details of its members; which however does not include the list of non-members. The present study presents information on HRH situation of registered Nepali dentists.

The present study showed that the number of dentists has increased remarkably after the year 2005, and the number of specialists after 2010; which are mainly due to the establishment of dental institutes in Nepal. The percentage of dentists graduated from Nepal increased from $19.4 \%$ to $55.4 \%$ in seven years. The number of specialist dentists was only 60 in 2008, ${ }^{16}$ which increased to 419 in 2015.

The study noted that the Nepali dental fraternity is gradually being dominated by female and young professionals. The present female and male proportion is 59.4 and 40.6; which was 57.7 and 42.3 in 2008 . Similarly, the present percentage of young dentists aged below thirty years is $47.6 \%$ as compared to $46.3 \%$ in 2008. ${ }^{16}$ 
The dentist to population ratio in Nepal has dropped down exponentially in recent decades. Based on the total number of dentists, the present ratio is $1: 16000$ as per the population report of Central Bureau of Statistics. ${ }^{17}$ The ratio was $1: 24000$ in the year 2010 and 1:120000 in 2000. The dentist-population ratio in the capital and major cities is gradually decreasing; which however remains very high in rural areas of Nepal. In comparison to global context; the dentist population ratio per 10,000 populations was 0.8 in India, Sri Lanka, 0.6 in Pakistan, 0.4 in China, 0.3 in Afghanistan and 0.2 in Bangladesh in 2012. ${ }^{18}$ The calculated dentist population ratio in 2012 was 0.5 in Nepal; the ratio is comparable in the region. This ratio is ten folds high in developed countries; e.g. Norway 8.9, Germany 7.8, Japan 7.4, Australia 6.9, UK 5.3. ${ }^{18}$

The study experienced intricacy in finding detail information about the dentists especially new graduates. Thus, few voids appeared in the report.

\section{CONCUSIONS}

The total number of registered Nepali dentists was 1803 with 419 specialists until June 2015. Among all; 60\% were professionally active, rest were studying post graduate level or not working. More than one-fourth dentists were living outside the country; most of them were either employed or studying post graduation. Among the professionals; about $60 \%$ dentists were working in Kathmandu valley and more than three-fourth were employed in private sector. Majority of the dentists working in public sector and academia serve extra time at private clinics.

The dentist-population ratio is decreasing exponentially in capital and major cities of Nepal however it remains very high in rural areas. Very few dentists serve in Province 6 and Province 7 regions.

\section{ACKNOWLEDGEMENT}

The authors would like to thank Dr Shiva Raj Adhikari and Mr Vishnu Sapkota; Health Economists for guiding the research project, acknowledge Institute of Nepal Environment \& Health Development (INEHD) and GIZHealth Support Program for financially supporting the research project.

Sincere gratitude to Nepal Medical Council, Nepal Dental Association and its regional branches, Oral Health Focal Point, Department of Health Services/Ministry of Health, dental/medical colleges, private health institutions, and all dentists for sharing information.

\section{REFERENCES}

1. Magar A. Human resource for health in Nepal (Editorial). J Nep Health Res Counc. 2013;11(2):I-II. Link

2. Dixit S. Dental manpower status in Nepal. J Nep Dent Asso. 2009; 10(1):1-2.

3. Ministry of Health \& Population. National Oral Health Policy-Nepal 2004, Revised 2014. Available from: http:// www.mohp.gov.np/index.php/...1/policy

4. Ministry of Health \& Population. Nepal Health Sector Program-II (NHSP-II) 2010-2015. Available from: nhsp. org.np/wp-content/uploads/2014/11 / NHSP-II-Final. pdf

5. Bongaarts J. World Health Organization: Working Together for Health: The World Health Report 2006. Population and Development Review. 2006 Dec 1;32(4):790-2. Link

6. Oral health workforce planning for developed countries. A discussion paper from the FDI Dental Practice Committee. Int Dent J. 2005; 55(1):42-4.

7. Bhandari Baral B, Prajapati R, Karki KB. Distribution and skill mix of health workforce in Nepal. J Nepal Health Res Counc. $2013 ; 11(24)$ : 126-32.Link

8. List of the Doctors Registered in Nepal medical Council (1961-23 $3^{\text {rd }}$ July, 2013).Published by Nepal Medical Council, Kathmandu, Nepal; 2013. Available from: http: / /www.nmc.org.np/

9. Central Bureau of Statistics http://cbs.gov.np/image/ data/Population/CasteEthnicity/ Caste.pdf. Available from:

10. Bhattachan KB, Sunar TB, Bhattachan YK, Caste-based discrimination in Nepal. Working Paper Series. Indian Institute of Dalit Studies, New Delhi. 2009; 3:9.idsn. org / .../New.../Nepal/Caste-based_Discr..

11. Available from: http://www.nmc.org.np/search.html

12. Dental Directory-Nepal 2013. Published by Nepal Dental Association. Kathmandu, Nepal; 2013.Link

13. https://www.census.gov/population/international/ software/cspro/

14. nhsp.org.np/human-resource-information-systemassessment-2/

15. http://www.pis.gov.np/

16. Shrestha S, Maharjan SK. Facts about Nepalese Dentists. Dent Nep. 2008; 3(1):31.

17. Central Bureau of Statistics.cbs.gov.np/sectoral_statistics/ population

18. World Health Organization. The World Statistics 2012. apps.who.int/iris/ bitstream/10665/44844/1/9789241564441_eng.pdf \ Link 